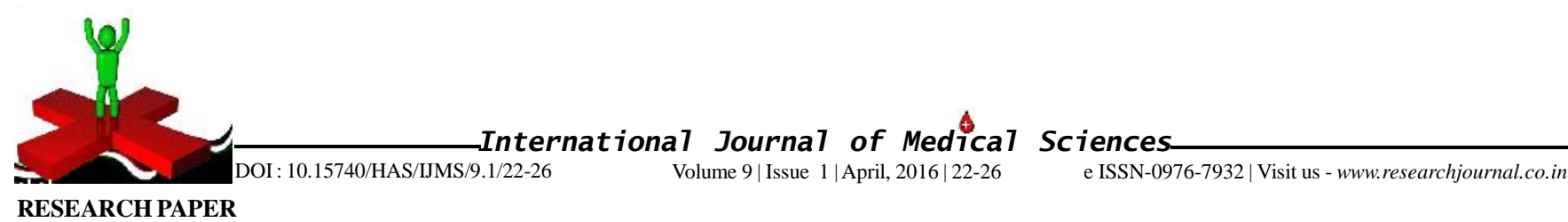

\title{
Percieved Usefulness of Yashaswini Health Scheme
}

\section{PAVITHRA C. HAMPANAVAR AND L. MANJUNATH}

See end of the paper for authors' affiliation

Correspondence to : PAVITHRA C.

\section{HAMPANAVAR}

University of Agricultural Sciences, DHARWAD (KARNATAKA) INDIA

\section{KEY WORDS :}

Percieved usefulness, Yashaswini health scheme
ABSTRACT : Health is one of the vital indicators of human development. Health standards in India have improved considerably since independence. The efforts of the government and other agencies engaged in expanding the health infrastructure have paid off well as evidenced by the improvement in some of our health indicators. Government has made deeper inroad into rural areas with focused schemes like the Yashaswini and even started a scheme for health insurance for the poor population. Creating bridge between farmers and their need to live a healthy life, Yashaswini scheme has brought quality healthcare to the farmers' doorstep in the state. A study was conducted to analyze the perceived usefulness of Yashaswini Health Scheme during 2012-13 in Belgaum district of Karnataka state. Purposive random sampling technique was used for the selection of four blocks i.e., Ramdurg, Savadatti, Gokak and Bailhongal. One hundred and twenty farmers from eight villages were selected from four taluks. The overall perceived usefulness level of the beneficiaries was high i.e., 44.16 per cent and 66.66 per cent, respectively. Most of them have undergone the direct benefits like eye operation, stomach ulcers, hernia, caesarean and uterus operation with 5,000 to 10,000 financial assistance.

How to cite this paper : Hampanavar, Pavithra C. and Manjunath, L. (2016). Percieved Usefulness of Yashaswini Health Scheme. Internat. J. Med. Sci., 9(1) : 22-26. 